\title{
Understanding "Elder Abuse and Neglect": A Critique of Assumptions Underpinning Responses to the Mistreatment and Neglect of Older People
}

\author{
JOAN HARBISON, PhD, RSW \\ School of Social Work, Dalhousie University, Halifax, Nova Scotia, Canada \\ STEPHEN COUGHLAN, LLM, PhD \\ Faculty of Law, Dalhousie University, Halifax, Nova Scotia, Canada \\ MARIE BEAULIEU, PhD \\ Department of Social Work and Gerontology Research Centre, University of Sherbrooke, \\ Sherbrooke, Quebec, Canada \\ JEFF KARABANOW, PhD \\ School of Social Work, Dalhousie University, Halifax, Nova Scotia, Canada \\ MADINE VANDERPLAAT, PhD \\ Department of Sociology and Criminology, Saint Mary's University, Halifax, Nova Scotia, \\ Canada \\ SHEILA WILDEMAN, LLB, MA \\ Faculty of Law, Dalhousie University, Halifax, Nova Scotia, Canada \\ EZRA WEXLER, BSW, RSW \\ School of Social Work, Dalhousie University, Halifax, Nova Scotia, Canada
}

The authors wish to acknowledge with thanks the funding of the studies that provided the empirical background for this article. The first study in the province of Nova Scotia was funded by the Nova Scotia Department of Community Services and the federal Department of Justice of Canada. The second study in Nova Scotia was funded by the Nova Scotia Health Research Fund. The study of all three Maritime Provinces is being funded by the Social Sciences and Humanities Research Council of Canada.

This article is adapted from a background paper prepared for Human Resources and Skills Development Canada, August 31, 2008.

Address correspondence to Joan Harbison, Dalhousie University, School of Social Work, Suite 3201, 1459 LeMarchant Street, Halifax, Nova Scotia B3H 3P8, Canada. E-mail: joan.harbison@dal.ca 
This article provides an overview of the ways in which the mistreatment and neglect of older people have come to be understood as a social problem, one which is underpinned by a variety of substantive and theoretical assumptions. It connects the process of conceptualizing elder abuse and neglect to political-economic and social evolution. The authors draw on a review of the literature, government sources, interest group websites, and their own research to provide a critical commentary illustrating bow these understandings have become manifest in legislation, policies, and programs pertaining to "elder abuse and neglect" in Canada. Suggestions are provided for changes in direction for policies, programs, and research.

\section{KEYWORDS assumptions, elder abuse and neglect}

\section{INTRODUCTION}

The term "elder abuse and neglect" is in common usage as if it were a single phenomenon. However, it is widely acknowledged in the literature that it does not represent a single problem, but many different problems (Coughlan et al., 1995; Harbison \& Morrow, 1998). Indeed current categorizations include matters as diverse as physical/sexual and emotional/psychological abuse along with financial exploitation and violation of rights. For this reason, we use the term "elder abuse and neglect" in inverted commas, but also refer generically to "mistreatment and neglect." We use a perspective of contextual construction (Best, 1989) in support of the notion that the social construction of "elder abuse and neglect" is subject to influences associated with changes in the structure of Canadian society, increasing cultural diversity, and our understanding of aging itself (Chappell, Gee, McDonald, \& Stones, 2003).

Our discussion is focused on how mistreatment and neglect are understood and how these understandings have been manifest in responses within Canadian society. Within the Canadian federal state jurisdiction most aspects of health and family life lie with the provincial and territorial governments. As a consequence of these constitutional arrangements, formal responses to incidences of mistreatment and neglect, whether based on legislation or programs, are unique to each province or territory. This is notwithstanding a variety of recent federal/provincial/territorial activities that are indicative of a growth in acknowledgment of issues surrounding "elder abuse and neglect."

The article begins with a discussion of how the coalescence of a number of social conditions led to constructions of older people as in need of care and protection by professionals. It traces the professionally led lobby 
for acceptance of "elder abuse and neglect" as a social problem requiring the intervention of the state and considers the efficacy and impact of the legislative solutions that are a consequence of this lobby. It examines the contradictions, positive potential, and dangers inherent in new and competing constructions of older people, with regard to their position in society. Finally it points to the need to move beyond the current conceptualization of "elder abuse and neglect" in order to offer resources and services specific to the diverse problems subsumed under the term.

\section{POLITICAL, ECONOMIC AND SOCIAL CONDITIONS, AND THE EMERGENCE OF "ELDER ABUSE AND NEGLECT"}

It has been argued in both North America and Europe that the reasons for the particular trajectory of "elder abuse and neglect" and its evolution as a social problem lie in its socioeconomic and political context (Baumann, 1989; Kosberg, Lowenstein, Garcia, \& Biggs, 2003; Leroux \& Petrunik, 1990; Ogg \& Munn-Giddings, 1993). In the 1950s, there was an overabundance of workers at the same time that employers wanted to renew their labor force in response to new technologies and new needs (Townsend, 1986). This resulted in policies that forced older people to retire. The state pensions that accompanied these retirements changed the status of older workers from that of paid employees to recipients of state support. This process of "welfarization" has been said to lead not only to older people's marginalization in society but also in many instances to poverty (Fennel, Phillipson, \& Evers, 1988). Townsend suggests that it may be difficult for the public to accept that much of the social dependency of older people was artificially created, leading to an "institutionalized ageism . . . developed to suit the management of industry and the economy in capitalist and state socialist societies alike ..." (1986, p. 43; see also Macnicol, 2006).

A theory of aging that viewed old age as a gradual disengagement from life (Cumming \& Henry, 1961) with retirement as the major step in this disengagement emerged fortuitously at the same time as the labor market policies described above. Indeed "Cumming and Henry argue that aging cannot be understood separate from the characteristics of the social system in which it is experienced" (Lynott \& Lynott, 1996, p. 751). Despite alternative constructions emphasizing old age as a time of activity, disengagement theory has had a powerful and continuing effect on societal perceptions of older people (Estes, Biggs, \& Philippson, 2003; Lynott \& Lynott, 1996). The workplace is a good example of this. Some older workers, by keeping their positions, are accused of preventing the proper progress of younger ones (McPherson \& Wister, 2008).

Thus the concept of "elder abuse and neglect" was developed in an era when older people were identified as a homogenous group based 
on chronological age and were marginalized by an understanding of their declining capacities that was associated with their exclusion from the labor market and with a perception that their roles in society should be increasingly limited. Ambivalence about older people's capacities remains embedded in society. On the one hand, people are portrayed as having the ability to "age successfully" in mind and body (Rowe \& Kahn, 1998); on the other, their mental and physical capacities are constantly under surveillance in anticipation of their decline (Byetheway, 1995).

\section{"Experts" and the Establishment of "Elder Abuse and Neglect" as a Social Problem}

The social conditions linked to negative views of aging as decline and disengagement from society, described above, provided little encouragement to the old to see themselves as political actors in addressing their problems (Williamson, 1998). Further, concurrent with these socioeconomic events was a recognition of population aging and with it the expansion and development of gerontology - the study of aging (Markson, 2003). Given the prevailing conceptualization of old age in general as a problem, some gerontologists saw it as their role, as "experts" in the field of aging, to become involved: "Professional social problem solvers supply leadership in the construction of a problem, its theory of explanation and its policies to alleviate the problem" (Gusfield, 1982, p. 6, cited in Baumann, 1989, p. 56). The interdisciplinary and applied character of gerontology led its members to a particular interest in elder abuse:

Professionals across service sectors, from banking and insurance to social work and law became especially concerned about the growing number of mentally impaired older people living alone, often without nearby family support. It was feared that many could not provide for their own care or protection without community intervention. (Anetzberger, 2005, p. 2)

From its beginnings as a social problem, "elder abuse and neglect" was shaped as a problem that required professional expertise because of the particular characteristics of helplessness, vulnerability and frailty assigned to the older population: ". . . the elderly themselves have in the main either not taken part in or been left out of the loop of agencies that assume responsibility for dealing with problems related to old age" (Leroux \& Petrunik, 1990, p. 654).

This professionalization of their problems of mistreatment and neglect placed older people in a parallel situation to children in terms both of their characterization as being "in need of protection" and the need for professional expert responses to their situations. Moreover, how older people 
themselves, especially those who are victims of mistreatment and neglect, view their own situations has rarely been investigated (Hightower, Smith, \& Hightower, 2006). We do know that some older people wish to maintain autonomous lives, including privacy regarding mistreatment, especially where it may lead to questions about their judgment (Vinton, 1991). In addition, many older people wish to remain within their abusive families (Harbison, Coughlan, Karabanow, \& VanderPlaat, 2005) to retain a sense of positive identity and of belonging to family and culture (Podnieks, 1992; Tam \& Neysmith, 2006), as well as for reasons of fear and shame (Barer, 1997). Older people themselves then, whether covertly or unwittingly, often do not lend their support to efforts to strengthen "elder abuse and neglect" as a public social problem.

\section{Toward a Fully Fledged Social Problem}

Not all social problems that receive initial recognition become fully fledged. Whether a set of harmful conditions becomes a recognized "social problem" depends to a great extent on the nature, power, and tenacity of those groups making the claims about the social conditions (Best, 1989) and perhaps to a lesser extent on the "attractiveness" of the problem itself. Yet despite society's ambivalence about older people and the reservations of some older people themselves, the idea of "elder abuse and neglect" as a social problem has gained momentum over time.

In the view of Leroux and Petrunik-using Blumer's five-stage model of social problems - the idea of elder abuse as a social problem emerged from "the public perception of old age as a social problem" where "old age overrides all other statuses and has the most priority in the characterization of the individual" (1990, p. 653). Based on the perception of old people as frail in mind and body there is "an assumed need to protect the elderly" through professional intervention. Moreover, this construction "overrides their status as legally and socially competent adults" (1990, p. 653).

To attain legitimation, according to Blumer's model, it is necessary, but not sufficient, for a problem to be recognized by professionals and to be the subject of claims made by particular interest groups within particular provinces and municipalities. In a federal state such as Canada it also requires legitimation from the federal level. Leroux and Petrunik pointed out that in 1990 there was "no unified national lobby speaking on its behalf" and therefore limited acknowledgment of the issue by the federal government; this was mainly visible through research grants assigned in recognition of elder abuse as a part of family violence (p. 658).

Twenty years later a national lobby group for elder abuse-the Canadian Network for the Prevention of Elder Abuse (CNPEA), consisting of stakeholders from professional, provincial/governmental, academic, and 
older people's organizations - is in place, although it runs on a shoe-string budget, and at present it receives no direct sustaining funding. One also can readily cite many current activities at the federal level in support of issues of elder abuse. These include the establishment by the federal government of the National Seniors Council on Elder Abuse under the leadership of Senator Margory LeBreton. The Report of the National Seniors Council on Elder Abuse states that "momentum for action on elder abuse is building within the federal government" (National Seniors Council, 2007, p. 5). This momentum includes recent funding for elder abuse awareness projects under a Federal Elder Abuse Initiative established in 2008, which is led by Human Resources and Skills Development Canada (HRSDC) and includes participants from the Public Health Agency of Canada, Department of Justice, and Royal Canadian Mounted Police.

A separate Special Senate Committee on Aging has recently published its Final Report (April, 2009). The report frames its discussion of abuse and neglect in terms of an ageism that leads to an unjust stripping of older people's rights and is too often "self-adopted" (p. 6). Further, the commissioning of background papers on a variety of elder abuse topics by HRSDC (2008) and the federal Department of Justice provided a knowledge base for future research and policy development in the area.

A federal/provincial/territorial subcommittee on elder abuse shares information about initiatives within each jurisdiction and organized a national Elder Abuse Forum in Vancouver in November 2007. In addition, all of the provincial and territorial governments have some form of policies and programs relating to elder abuse, and nearly all took part in activities for World Elder Abuse Awareness Day declared by the United Nations and supported by Canada's Governor General (June 15, 2007). The attorney general of Canada, one of the keynote speakers at a national conference on elder law organized by the Canadian Centre for Elder Law Studies (Vancouver, November 9, 2007) stated that "elder abuse is an issue whose time has come."

\section{A Cautionary Note}

Yet, despite all this attention to the "problem of elder abuse," there are several complicating factors that inhibit the development of "elder abuse and neglect" as a nationally recognized "social problem." Activities are still focused on initiatives that are intended to describe what the problems are and to make people aware that they exist. There is as of yet no "mobilization of action" aimed at federal provision of universal programs (Leroux \& Petrunik, 1990). Jurisdictional and conceptual issues aside, the most important factor in the construction of "elder abuse and neglect" as a social problem at the level of government policy is the fact that both federal and provincial governments no longer see it as their role to take on new 
initiatives that require funding that is structural and permanent (Lightman, 2003).

Governments also are bound to follow what the public wants. In Canada the chief lobby for action on elder abuse comes from CNPEA, which includes professionals, academics, community organizations (including those of seniors), and elder abuse consultants affiliated with provincial governments, as well as from other individuals and groups with similar characteristics (National Seniors Council, 2007, p. 9). In that sense the concluding statement of Leroux and Petrunik that "concern over elder abuse thus far . . . derives more from professional interest group advocacy than from widespread societal reaction or even a popular movement" (1990, p. 661) remains true. Although the present momentum suggests that this might change, it is important to consider why progress on establishing "elder abuse and neglect" as a social problem has taken so long. One possibility is that the lobbyists' efforts follow the indeterminate nature of "elder abuse and neglect," thus remaining fragmented rather than clearly focused. Another is that there are two distinct sets of problems with regard to the mistreatment and neglect of older people: "those that older people actually have and those that experts think they have" (Leroux \& Petrunik, 1990, p. 661)—a possibility that requires careful consideration in the building of a research agenda.

Finally, one explanation that Leroux and Petrunik do not emphasize is the caution of legal experts about legal and professional responses and interventions that do not sufficiently consider individual rights. Policymakers may wish to avoid exacerbating the tensions between those who concern themselves with rights and autonomy and those professionals and members of the public who want "stronger" legislation that sanctions more intrusive interventions (Coughlan et al., 1995). A case in point is a public consultation initiated by the Nova Scotia government with a view to reforming the Nova Scotia Adult Protection Act, which resulted in deadlock because of the opposing views of these two groups.

\section{LEGISLATION AS A SOLUTION TO "ELDER ABUSE AND NEGLECT"}

\section{The Impact of Legislation on Services}

Adult protection legislation is often seen by public and professionals alike as having the ability to provide satisfactory solutions to problems of the mistreatment and neglect of older people. However, there are a number of reasons to question both the appropriateness and the efficacy of these approaches. Indeed, from the earliest literature on elder abuse, in Canada and elsewhere, many concerns have been raised about the effects of adult protection legislation (Robertson, 1995). Chief among these is that adult protection legislation was modeled on the legislation used to protect children. 
This raised the question of whether older adults were being viewed and treated as if they had the same characteristics as children. Indeed many legal scholars warned that this was so and argued that the role of the state as parens patriae is not an appropriate relationship for older people.

A number of challenges to the above-noted legislative "solutions"challenges that call for the rejection not only of parens patriae as the appropriate legal framework, but of the assumption that chronological aging is representative of a state of mental decline-have been raised in the literature (Coughlan et al., 1995; Kohn, 2009; McDonald \& Wigdor, 1995; McDonald, Hornick, Robertson, \& Wallace, 1991; Poirier, 1992). Among the issues raised are whether legislative solutions support a tendency to undermine the rights and autonomy of older people by providing more intrusive interventions than would otherwise be the case: for instance, if assistance were instead offered directly through health or social services or informally in communities (Harbison et al., 2005). A corollary of this is whether mistreated and neglected older people may be further marginalized by legal interventions, which are by their very nature paternalistic. That is, they assume that a "rights-based" approach is inappropriate and that decisions about how the elderly will live should primarily be based on some external standard judging their "best interests" rather than on their own wishes (Coughlan et al., 1995). They take as a starting point the question of whether or not a person has the capacity to make decisions for him or herself. In so doing such interventions not only fail to address the issue of services, they also fail to address the difficulties inherent in assessing capacity and that the need for capacity varies according to purpose and context (Wahl, 2007).

An ever-present danger with adult protection legislation, especially given the limited provisions for advocacy and independent legal representation of older adults (Coughlan et al., 1995; Gordon, 2001) is that their rights will not be respected. Research by Poirier found that "the most important factor in determining whether or not protective measures are ordered is whether or not the client has a lawyer," and that in addition "the legal philosophy of the judge has a significant outcome on the case" (cited in McDonald \& Wigdor, 1995, p. 4).

\section{Rights to Services and Constructions of Older People}

In addition to the many arguments that legal solutions have only a limited role to play, attention has been brought to their propensity to distract our attention from the need for "adequate funding for proper support services and programs in the community" in that legislation offers a very public appearance of doing something about a problem without committing many resources - a strategy that holds great attraction for governments (Robertson, 1995 , p. 55). At the same time, social theorists, notably Foucault, have fuelled explorations of the tendency for Western industrial states to become 
preoccupied with surveillance, risk, and safety while leaving families and "communities" to provide necessary assistance (Biggs \& Powell, 1999; Webb, 2006). In fact, it may be that "an important cause of increased vulnerability with age is the structural inequality built into our society" (Atchley, 1990 , p. 21), one that includes discrimination in employment, and financial, housing, and transportation inequities. This critique is borne out by the fact that in Canada, for instance, few dedicated programs or services have been attached to adult protection legislation. Instead, for the most part, either small numbers of adult protection workers are charged with investigation and referral of the cases identified, or workers within existing services are designated to carry out the adult protection functions. Workers face enormous challenges in these roles, especially given that most situations referred are those of self neglect. Our research suggests that most often they vigorously attempt to respond to an older person's needs and wishes despite the lack of resources (Harbison et al., 2005; Harbison, McKinley, \& Pettipas, 2006).

Providing appropriate services under adult protection legislation is further complicated by the fact that "elder abuse and neglect" "is not a single phenomenon, and it is not distinct from other phenomenon [so that] to talk about a legislative response to 'elder abuse' is to mask fundamental differences between various types of problems" (Coughlan et al., 1995). These may include material abuse, chronic verbal aggression, physical violence, and neglect as indicated in the findings of the study by Podnieks and Pillemer (1990). Coughlan et al. argue that based on this and similar evidence that the issue is multifaceted, "no one would suggest that . . . [for] the population as a whole . . . we should pass a law to deal with "the problem"" (1995, p. 30). Why then are we so inclined to treat the issue as amenable to a single legislative response in the case of older people? One explanation why legal responses to "elder abuse and neglect" have been so frequently invoked seems to lie in the idea of age as an overriding "master status" noted earlier-where perceptions of all old people as frail in mind and body lead to "an assumed need to protect the elderly" in many dimensions of their lives (Leroux \& Petrunik, 1990, p. 653).

A number of issues surround the offering of services including whether, if they are refused, as is often the case, this is on account of duress or mental incapacity or because they are not services that are acceptable to the older person, or perhaps for reasons of shame or a need for independence (Barer, 1997). For instance, most older people are strongly against placement in a "nursing home" —often the only alternative available-but might accept services in their home (Harbison et al., 2005). Yet refusal of a placement in residential care in itself can make them eligible for placement under a court order for provision of services. A recent case taken to the Supreme Court of Canada, Nova Scotia (Minister of Health) v. J. J., established that the judge may intervene to order services that he or she considers to be in 
the "best interests" of the person who is the subject of a court order under Nova Scotia's Adult Protection Act.

The issue of just what rights older people have to the types of services that they need and want is a contentious one. Bickenstaff (2009), working on behalf of the United Nations, discusses issues surrounding absolute versus relative rights, and priority setting to achieve equity in just societies in the global context of finite resources. However, these explorations do not address the more profound questions presented by Ignatieff (2000), de Beauvoir (1970), and others, that ask us to examine the meanings for our society that can found in our responses to the needs of those in old agethat is, to those who are no longer considered productive in the terms of modern capitalist states.

\section{Apocalyptic Demography and Services for Older People}

We have earlier noted the differing interpretations of the social and economic effects of the aging of Canada's population. In the media and among the general public the increasing numbers of older people in our society are frequently viewed as a burden-for care, health, and social services (Rozanova, Northcott, \& MacDaniel, 2006). However, many demographers call this an "apocalyptic" version of the effects of population aging (Gee \& Gutman, 2000). Research also indicates that the economic and social effects of population aging have been overemphasized, including both on problems with debt and deficit and on their impact on the health and social service systems (Cheal, 2002; Evans, McGrail, Morgan, Barer, \& Hertzman, 2001; Mullan, 2002). It has been suggested that negative, blaming stereotypes of older people lend support to policies that seek to cut back social programs for care (Macnicol, 2006). Further, old people may internalize these negative versions of old age and therefore be reluctant to seek assistance (Aronson \& Neysmith, 2001).

Two contradictory constructions of older people are now current in our society. On the one hand, older people are portrayed as "youthful," energetic, and able and willing to work and contribute to society. While this portrayal may lead to older people's acceptance as workers and citizens, it may also "marginalize those older adults who do not match the new expectations" (Rozanova et al., 2006, p. 384). There is an even darker side to portrayals of the minority of older people who are truly frail and vulnerable_-as opposed to those who are constructed as such (Kane, 1990). Recently, reports in the media of research studies done in Canadian long term care facilities have portrayed older people not just as a burden but as people that are aggressive and abusive to those trying to care for them (Banarjee et al., 2008; Canadian Institute for Health Information, 2008). Such stereotyping can readily be linked to the most popular explanation for mistreatment and neglect of older people in family or family substitute 
settings, that of "caregiver stress"-an explanation whose limitations have long been discussed (Baltes, 1996; McDonald, Collins, \& Dengal, 2006).

\section{PRIVILEGING THE CONSTRUCTIONIST VIEW OF "ELDER ABUSE AND NEGLECT"}

As Biggs, Phillipson, and Kingston (1995) state, "the social construction of reality proposes that reality is created and maintained through social institutions that socialize their members into accepting certain definitions as objective fact" (p. 27). Moreover, these perceptions and definitions change over time and with them what we understand as "objective fact." For instance, within a societal context where labor market changes have meant that older people have become needed in the work force at the same time as the aging of the population has increased the cost of pensions, more attention has been paid to research that acknowledges the mental and physical capabilities of older age groups. In other words, older people are being reconstructed as fit to work. Mandatory retirement policies are being removed, and delaying the age of eligibility for federal pensions has been mooted in Canada, and implemented elsewhere. For some older people these policy changes will be welcome. For those who have not maintained good health into old age and who have had low paying jobs, with the result that they do not have private pensions or savings, delayed retirement will represent further discrimination unless policies are developed to address their circumstances (Macnicol, 2006).

\section{DISCUSSION}

Based on the discussion above, several arguments may be advanced concerning why our understandings of the mistreatment and neglect of older people have remained static over time. Further, it is suggested that if this lack of development in theorization continues it will have very serious consequences for the place of older people in our society.

\section{The Effects of Pragmatism on Theory Development}

There are a number of reasons why "pragmatism," as evidenced by a tendency to use existing ways of understanding and responding to new problems, has prevailed in the theories applied to the mistreatment and neglect of older people (Biggs et al., 1995, p. 19). First, as we have noted, "elder abuse and neglect" consists of a number of very different problems and thus is not easily amenable to definition or research. In these circumstances, ways of understanding mistreatment and neglect of older people have been appropriated from other more developed social problems-those 
of child abuse and family violence. Moreover, containing "elder abuse and neglect" within the rubric of family violence maintains it as primarily a problem of individual families or caregivers rather than acknowledging that it takes place not just in the family but in the contexts of paid community and institutional care, and through exploitation and discrimination in the wider society. Another important aspect of theories that confine our understanding of abuse within the family is that for the most part they were developed when cultural diversity in Canada was neither so present, nor so recognized as a significant dimension of Canadian society, as it is today (Beaulieu, Gordon, \& Spencer, 2005). Research and policies need to consider these new understandings of abuse in their development.

The Impact of Constructing Older People as Frail and Vulnerable

Constructions of aging that view older people as frail and vulnerable have led to a focus on providing legal remedies for mentally incapacitated older people, without the clear understanding that most older people are not mentally incapacitated. Moreover, statistics demonstrate that most people referred to adult protection service are suffering from self-neglect-not abuse or neglect by others. Further, limited alternative assistance is available to those older men and women who are perceived as capable. Overall, the focus on an "either/or" state of capacity has prevented the focus being on the provision of services that respond to the range of older people's needs, as opposed to the perception of their "best interests." We agree with the legal expert who told the National Seniors Council that "the law is not a solution; it is a tool" (2007, p. 12). Not only this, as we have discussed above, in practice legal interventions raise many issues about the rights, freedoms, and autonomy that are guaranteed to all citizens under the Canadian Charter of Rights and Freedoms. In particular, the use of adult protection legislation needs to be carefully monitored through the courts and through policy development and research.

\section{Acknowledging Diverse Needs for Assistance}

Services are rarely based on the expressed needs of older people. For most their greatest wish is to remain in their own "homes" whatever their circumstances. Thus where older people have been engaged in their own assessment of their needs, these have proven to be diverse-including a range of informal and formal in-home services, and various options for sheltered accommodation and housing (see for instance, the Older Women's Network, 1998). Needs also should be considered with reference to the differing practices and cultural norms of Canada's many ethno-cultural groups. In other words, responses should reflect the fact that "elder abuse and neglect" is not a single problem, just as "the old" are as diverse as any 
other age group. Research should knowingly focus on particular issues in relation to the experiences of specific groups of older people.

\section{Value-Based Assumptions Versus Empirical Evidence}

Much of what has occurred in response to the acknowledgement that "elder abuse and neglect" exists has been based on value-based assumptions rather than on empirical evidence. In addition, very few empirical studies of the mistreatment and neglect of older people, and how to address this, have been carried out in Canada. In particular, very few address the crucial connections between legislation and policy and how these work in practice. Further research is needed.

\section{The Need for Adequate Services}

Finally, we note one overriding theme identified early in the "career" of elder abuse and neglect as a social problem that has continued to be very present: "Without adequate funding, proper support services and programs in the community, any legal response, no matter how appropriate it may seem in theory is almost certain to fail" (Robertson, 1995, p. 55). The National Seniors Council Report on Elder Abuse (2007) echoes these concerns over ten years later: "participants . . . delivered a unanimous message that without adequate and sustainable funding, efforts to combat elder abuse in local communities are compromised" (p. 11).

\section{CONCLUSIONS}

"Elder abuse and neglect" is now well on its way to global acceptance as an established social problem. In our article we have sought to raise issues that suggest that in order to promote social justice in meeting the needs of older people we may need to disband the concept of "elder abuse and neglect" and the search for an overall unifying theory, and focus instead on understanding and addressing the range of problems that it represents. In so doing, it will be possible to address a variety of injustices perpetrated against older people and to fully acknowledge the diversity of older generations' needs and capacities.

\section{REFERENCES}

Adult Protection Act. (1989). R.S.N.S., 1989, c.2.

Anetzberger, G. J. (Ed.). (2005). The clinical management of elder abuse. New York, NY: Haworth Press. 
Aronson, J., \& Neysmith, S. (2001). Manufacturing social exclusion in the home care market. Canadian Public Policy, 27(2), 151-164.

Atchley, R. C. (1990). Defining the vulnerable older population. In Z. Harel, P. Ehrlich, \& R. Hubbard (Eds.), The vulnerable aged: People, services, and policies (pp. 18-33). New York, NY: Springer Publishing Company.

Baltes, M. M. (1996). The many faces of dependency in old age. Cambridge, England: Cambridge University Press.

Banerjee, A., Daly, T., Armstrong, H., Armstrong, P., LaFrance, S., \& Szebehehy, M. (2008). "Out of control": Violence against personal support workers in long term care. Unpublished manuscript, Department of Sociology, University of Toronto, Toronto, Ontario, Canada.

Barer, B. M. (1997). The secret shame of the very old: "I've never told this to anyone else." Journal of Mental Health and Aging, 3(3), 365-375.

Baumann, E.A. (1989). Research rhetoric and the social construction of elder abuse In J. Best (Ed.), Images of issues: Typifying contemporary social problems (pp. 55-74). New York, NY: Aldine de Gruyter.

Beaulieu, M., Gordon, R. M., \& Spencer, C. (2005). The abuse and neglect of older Canadians: Key legal and related issues. In A. Soden (Ed.), Advising the older client (pp. 197-233). Markham, Canada: Lexis Nexis, Butterworth.

Best, J. (Ed.). (1989). Images of issues: Typifying contemporary social problems. New York, NY: Aldine de Gruyter.

Bickenstaff, J. (2009, January 16). Presentation to the Health Law Institute, Dalhousie University, Halifax, Nova Scotia, Canada.

Biggs, S., Phillipson, C., \& Kingston, P. (Eds.). (1995). Elder abuse in perspective. Buckingham, England: Open University Press.

Biggs, S., \& Powell, J. (1999). Surveillance and elder abuse: The rationalities and technologies of community care. Journal of Contemporary Health, 4(1), 43-49.

Bytheway, W. (1995). Ageism. Buckingham, England: Open University Press.

Canadian Institute for Health Information. (2008). Caring for nursing home residents with behavioural symptoms. Information to support a quality response. Retrieved from http://www.secure.cihi.ca

Chappell, N., Gee, E., McDonald, L., \& Stones, M. (2003). Aging in contemporary Canada. Toronto, Canada: Prentice Hall.

Cheal, D. (Ed.). (2002). Aging and demographic change in Canadian context. Toronto, Canada: University of Toronto Press.

Coughlan, S., Downe-Wamboldt, B. D., Elgie, R. G., Harbison, J., Melanson, P. M., \& Morrow, M. (1995). Mistreating elderly people: Questioning the response to elder abuse and neglect. Volume 1: Legal responses to elder abuse and neglect. Halifax, Canada: Dalhousie University, Health Law Institute.

Cumming, E., \& Henry, W. E. (1961). Growing old: The process of disengagement. New York, NY: Basic Books.

de Beauvoir, S. (1970). Old age. Harmondsworth, England: Penguin Books.

Estes, C. L., Biggs, S., \& Phillipson, C. (2003). Social theory, social policy and ageing: A critical introduction. Maidenhead, England: Open University Press.

Evans, R. G., McGrail, K. M., Morgan, S. G., Barer, M. L., \& Hertzman, C. (2001). Apocalypse no: Population aging and the future of health care systems. Canadian Journal on Aging, 20 (supplement 1), 160-191. 
Fennel G., Phillipson, C., \& Evers, H. (1988). The sociology of old age. Milton Keynes, England: Open University Press.

Gee, E., \& Gutman, G. (2000). The overselling of population aging: Apocalyptic demography, intergenerational challenges, and social policy. Oxford, England: Oxford University Press.

Gordon, R. M. (2001). Adult protection legislation in Canada, models, issues and problems. International Journal of Law and Psychiatry, 24, 117-134.

Harbison, J. (2008). Stoic heroines or collaborators: Ageism, feminism and the provision of assistance to abused old women. Journal of Social Work Practice, 22(2), 221-234.

Harbison, J., Coughlan, S., Karabanow, J., \& VanderPlaat, M. (2005). A clash of cultures: Rural values and service delivery to mistreated and neglected older people in Eastern Canada. Practice: A Journal of the British Association of Social Workers, 17(4), 229-246.

Harbison, J., McKinley, P., \& Pettipas, D. (2006). Older people as objects not subjects: Theory and practice in situations of "elder abuse." In R. Alaggia \& C. Vine (Eds.), Cruel but not unusual: Violence in Canadian families. A sourcebook of history, theory and practice (pp. 467-502). Waterloo, Canada: Wilfrid Laurier University Press.

Harbison, J., \& Morrow, M. (1998). Questions and contradictions: A re-examination of the social construction of elder abuse and neglect. Ageing and Society, 18, 691-711.

Hightower, J., Smith, M. I., \& Hightower, H. C. (2006). Hearing the voices of abused older women. In M. J. Mellor \& P. Brownell (Eds.), Elder abuse and mistreatment: Policy, practice and research (pp. 205-227). New York, NY: Hawthorne Press.

Ignatief, M. (2000). The rights revolution. Toronto, Canada: House of Anansi Press.

Kane, R. A. (1990). Venerable and perhaps vulnerable: The nature and extent of vulnerability among the aged. In Z. Harel, P. Ehrlich, \& R. Hubbard (Eds.), The vulnerable aged: People, services, and policies (pp. 4-17). New York, NY: Springer Publishing Company.

Kohn, N. A. (2009). Outliving civil rights. Washington University Law Review, 86(5), 1053-1115.

Kosberg, J., Lowenstein, A., Garcia, J. L., \& Biggs, S. (2003). Study of elder abuse in diverse cultures. Journal of Elder Abuse \& Neglect, 15(3/4), 71-89.

Leroux, T. G. \& Petrunik, M. (1990). The construction of elder abuse and neglect as a social problem: A Canadian perspective. International Journal of Health Services, 20(4), 651-663.

Lightman, E. (2003). Social policy in Canada. Oxford, England: Oxford University Press.

Lynott, R. J., \& Lynott, P. P. (1996). Tracing the course of the theoretical development in the sociology of aging. The Gerontologist, 36(6), 749-760.

Macnicol, J. (2006). Age discrimination: An historical and contemporary analysis. Cambridge, England: Cambridge University Press.

Markson, E. W. (2003). Social gerontology today: An introduction. Los Angeles, CA: Roxbury Publishing Company.

McDonald, L., Collins, A., \& Dergal, J. (2006). The abuse and neglect of older adults. In R. Alaggia \& C. Vine (Eds.), Cruel but not unusual: Violence in Canadian 
families. A sourcebook of history, theory and practice (pp. 425-466). Waterloo, Canada: Wilfrid Laurier University Press.

McDonald, L., \& Wigdor, B. (1995). Editorial. Taking stock: Elder abuse research in Canada. Canadian Journal on Aging, 14(2), 1-14.

McDonald, L. P., Hornick, J. P., Robertson, G. B., \& Wallace, J. E. (1991). Elder abuse and neglect in Canada. Toronto, Canada: Butterworths.

McPherson, B. D., \& Wister, A. (2008). Aging as a social process: Canadian perspectives (5th ed.). Oxford, England: Oxford University Press.

Mullan, P. (2002). The imaginary time bomb: Why an ageing population is not a social problem. London, England: I. B. Tauris.

National Seniors Council. (2007, November). Report of the National Seniors Council on Elder Abuse. Retrieved from http://www.seniorscouncil.gc.ca/en/home. shtml

Ogg, J., \& Munn-Giddings, C. (1993). Researching elder abuse. Ageing and Society, $13,13-29$.

Older Women's Network/Kappel Ramji Consulting Group. (1998). Study of shelter needs of abused older women. Toronto, Canada: OWN.

Podnieks. E. (1992). Emerging themes from a follow-up study of Canadian victims of elder abuse. Journal of Elder Abuse \& Neglect, 4(1/2), 59-111.

Podnieks, E., \& Pillemer, K. (1990). National survey on abuse of the elderly in Canada. Toronto, Canada: Ryerson University.

Poirier, D. (1992). The power of social workers in the creation and application of elder protection statutory norms in New Brunswick and Nova Scotia. Journal of Elder Abuse \& Neglect, 4(1/2), 113-133.

Robertson, G. (1995). Legal approaches to elder abuse and neglect in Canada. In M. J. MacLean (Ed.), Abuse and neglect of older Canadians: Strategies for change (pp. 55-62). Toronto, Canada: Thompson Educational Publishers.

Rowe, J. W., \& Kahn, R. L. (1998). Successful aging. New York, NY: Pantheon Books.

Rozanova, J., Northcott, H. C., \& MacDaniel, S. A. (2006). Seniors and portrayals of intra-generational and inter-generational inequality in the Globe and Mail. Canadian Journal on Aging, 25(4), 376-386.

Special Senate Committee on Aging. (2009). Final report. Retrieved from http:// www.parl.gc.ca/Content/SEN/Committee/402/agei/rep/AgingFinalReport-e.pdf

Tam, S., \& Neysmith, S. (2006). Disrespect and isolation: Elder abuse in Chinese communities. Canadian Journal on Aging, 25(2), 141-151.

Townsend, P. (1986). Ageism and social policy. In C. Phillipson \& A. Walker (Eds.), Ageing and social policy: A critical assessment (pp. 15-44). Aldershot, England: Gower Publishing.

Vinton, L. (1991). Factors associated with refusing services among maltreated elderly. Journal of Elder Abuse \& Neglect, 3(2), 89-103.

Wahl, J. (2007). Capacity and capacity assessment in Ontario. Retrieved from http:// www.practicepro.ca/practice/PDF/Backup_Capacity.pdf

Webb, S. A. (2006). Social work in a risk society: Social and political perspectives. Basingstoke, England: Palgrave, MacMillan.

Williamson, J. B. (1998). Political activism and the aging of the baby boom. Generations, 22(1), 55-59 